\title{
ВИЗНАЧЕННЯ ВІДПОВІДНОСТІ ВЛАСТИВОСТЕЙ МОДИФІКОВАНОГО ЛЛЯНОГО ВОЛОКНА ДЛЯ ОДЕРЖАННЯ ТОВАРІВ МЕДИКО-ГІГІЄНІЧНОГО ПРИЗНАЧЕННЯ
}

Т.О. КУЗЬМИНА

Херсонский наииональный технический университет

\author{
ОПРЕДЕЛЕНИЕ СООТВЕТСТВИЯ СВОЙСТВ \\ МОДИФИЦИРОВАННОГО ЛЬНЯНОГО ВОЛОКНА ДЛЯ \\ ПРОИЗВОДСТВА ТОВАРОВ МЕДИКО-ГИГИЕНИЧЕСКОГО \\ НАЗНАЧЕНИЯ
}

T. KUZMINA

Kherson national technical university

\section{DETERMINATION OF THE CONFORMITY OF PROPERTIES OF MODIFIED FLAX FIBER FOR THE GOODS OF MEDICAL AND HYGIENIC PURPOSE}

\section{https://doi.org/10.36910/6775-2310-5283-2019-12-15}

Мета. Дослідження гігроскопічних властивостей модифікованого лляного волокна та можливості отримання з нього гігієнічної вати.

Методика. Під час дослідження використовували стандартні методи визначення фізико-механічних та гігроскопічних властивостей волокнистого матеріалу, обробку результатів дослідження здійснювали методами математичної статистики.

Результати. Модифікація короткого лляного волокна дає можливість скоротити витрати на виробництво широкого асортименту лікувального одягу та матеріалів, тому актуальним $\epsilon$ аналіз впливу різних технологічних прийомів переробки короткого льоноволокна на його санітарно-гігієнічні властивості. Модифіковане лляне волокно, отримане при виконанні даної роботи із застосуванням емульсування комплексними хімічними препаратами (КХП) на основі фосфату карбаміду та поверхнево-активних речовин перед механічною обробкою, може бути використане для одержання медичної вати, оскільки має такі якісні показники: середня масодовжина 29,8 мм (при вимогах 18,530 мм); лінійна густина 0,85 текс при вимогах 0,20-0,90 текс); вміст костриці та смітних домішок 1,25\% (при вимогах 1,25-2,0\%). Були визначені показники санітарно-гігієнічних властивостей модифікованого лляного волокна, одержсаного різними способами. Встановлено, щуо жоден з етапів модифікації так не впливає на поглинальну здатність $i$ капілярність волокна, як варіння. Значне підвищення капілярності волокна (до 67,5 75,0 мм) в процесі лужного варіння в оптимальних умовах пояснюється депектинізацією, делігнірікацією та розщепленням комплексних волокон на більш тонкі комплекси. Модифікація цеелюлози, щฺо має місие при високотемпературному лужному варінні, сприяє 
поліпшенню поглинальної здатності волокна. Так, поглинальна здатність короткого модифікованого лляного волокна № 2 після лужного варіння становить 20,0 г/2, а для короткого модифікованого лляного волокна № 3 - 21,0 г/2.

Варіння лляного волокна проводили однофазним лужно-перекісним способом. При такому способі можна одержати високоякісне модифіковане льоноволокно й скоротити витрати на виробництво медичної гігроскопічної вати.

У результаті проведених досліджень розроблено науково обгрунтовану технологію отримання модифікованого лляного волокна, яке може бути використано для виготовлення медичної гігієнічної вати та інших товарів медико-гігієнічного призначення.

Наукова новизна. Обтрунтовано можливість використання модифікованого лляного волокна для виготовлення гігієнічної вати.

Практична значимість. Розроблено технологічний режим отримання медичноі гігієнічної вати з використанням лужно-перекісного варіння модифікованого лляного волокна.

Ключові слова. Модифіковане лляне волокно, капілярність, поглинальна здатність, медична гігієнічна вата.

\section{Постановка проблеми у загальному вигляді і її зв'язок з важливими} науковими та практичними завданнями. В останні роки спостерігається стійка світова тенденція збільшення попиту на гігроскопічні целюлозні матеріали та широкий асортимент продуктів на їх основі, в тому числі медичної вати [1 - 4]. В Україні сировинним джерелом для виготовлення вати $\epsilon$ імпортована бавовна. У зв'язку з цим актуальні дослідження, спрямовані на розробку технології виробництва гігроскопічних матеріалів 3 вітчизняної лляної сировини, а саме, волокнистих відходів переробки льону, обсяг яких становить 75-80 \% від загальної кількості виробленого льоноволокна.

Унікальні антисептичні властивості лляного волокна ставлять його на перше місце серед натуральних волокон для виробництва різних санітарногігієнічних матеріалів. Застосування нових технологій модифікації короткого льняного волокна дає можливість скоротити витрати на виробництво широкого асортименту лікувального одягу i матеріалів, тому актуальним $\epsilon$ дослідження фізичних властивостей лляного волокна та виявлення можливості його використання для санітарно-гігієнічних товарів [5 - 7].

Виробництво медичної вати 3 короткого льоноволокна орієнтує виробників медичної продукції на використання недорогої, щорічно відтворюваної вітчизняної сировини, сприяє зниженню споживання імпортного, дефіцитного i дорогого бавовняного волокна, розширює асортимент нових ефективних товарів для використання в лікувальній i хірургічній практиці, побуті, косметології [1].

Аналіз останніх досліджень, у яких започатковано вирішення проблеми. Розроблені останнім часом технології модифікації короткого лляного волокна дають можливість одержувати на його основі вироби 
медичного призначення, у тому числі вату й ватоподібні волокнисті матеріали, атравматичні пов'язки, тканини й комбіновані перев'язувальні засоби, неткані санітарно-гігієнічні матеріали.

Загальна схема процесу включає очищення сировини від костриці i інших сторонніх домішок, розволокнення комплексів та укорочення волокна, механічну і хімічну активізацію поверхні волокна, варіння і вибілювання, мокре розпушення волокнистої маси і їі сушіння, потім тіпання, чесання, пресування і пакування. Одержуваний продукт в порівнянні 3 бавовняною ватою має певні переваги: добру шаруватість, підвищену капілярність 80-85 мм проти 67 мм за ГОСТ 5556-81 «Вата медицинская гигроскопическая», вологопоглинання 20-30 г/г проти 19-20 г/г за ГОСТом. Льняна вата дозволяє ефективніше вбирати і утримувати рідкі виділення $з$ ран, а також швидше змочуватися розчинами лікарських засобів. Лляний матеріал має інтенсивну, відмінну від бавовняних матеріалів, сорбцію бактерій і грибів, підвищеними протигнилісними властивостями [2]. Але в Україні дослідження гігієнічних властивостей модифікованих лляних волокон майже не проводяться.

Цілі статті. Ціллю даної роботи $є$ дослідження гігроскопічних властивостей модифікованого лляного волокна та можливості отримання 3 нього гігроскопічної вати.

Об’скт дослідження. Коротке лляне волокно №2, №3 та модифіковане лляне волокно різних способів модифікації, отримане у лабораторних умовах.

Методи дослідження. Під час дослідження використовували стандартні методи визначення фізико-механічних та гігроскопічних властивостей волокнистого матеріалу, обробку результатів дослідження здійснювали методами математичної статистики.

Виклад основного матеріалу дослідження 3 повним обгрунтуванням отриманих наукових результатів. Модифікація короткого лляного волокна дає можливість скоротити витрати на виробництво широкого асортименту лікувального одягу та матеріалів, тому актуальним $\epsilon$ аналіз впливу різних технологічних прийомів переробки короткого льоноволокна на його санітарно-гігієнічні властивості.

Модифіковане лляне волокно, отримане при виконанні даної роботи із застосуванням емульсування комплексними хімічними препаратами (КХП) на основі фосфату карбаміду та поверхнево-активних речовин перед механічною обробкою [8], може бути використане для одержання медичної вати, оскільки має такі якісні показники: середня масодовжина 29,8 мм (при вимогах 18,530 мм); лінійна густина 0,85 текс при вимогах 0,20-0,90 текс); вміст костриці та смітних домішок 1,25 \% (при вимогах 1,25-2,0 \%) [9]. 
У роботі були визначені показники санітарно-гігієнічних властивостей модифікованого лляного волокна, одержаного різними способами. Виявилося, що жоден $з$ етапів модифікації так не впливає на поглинальну здатність і капілярність волокна, як варіння (табл. 1), що також підтверджується кінетичними кривими капілярного всмоктування (рис. 1).

Таблиця 1

Санітарно-гігієнічні властивості короткого лляного волокна

\begin{tabular}{|l|c|c|}
\hline \multicolumn{1}{|c|}{ Способи обробки } & \multicolumn{1}{|c|}{$\begin{array}{l}\text { Поглинальна } \\
\text { здатність, г/г }\end{array}$} & Капілярність, мм \\
\hline 1. Вихідне коротке лляне волокно & $8,5 / 8,5$ & $4,0 / 5,0$ \\
\hline $\begin{array}{l}\text { 2. Модифіковане лляне волокно, отримане } \\
\text { з емульсуванням КХП } \\
\text { додецилбензолсульфокислотою }\end{array}$ & $10,0 / 10,3$ & $12,3 / 13,0$ \\
\hline $\begin{array}{l}\text { 3. Модифіковане лляне волокно, отримане } \\
\text { з емульсуванням КХП з етильованим } \\
\text { нонілфенолом АФ9-10 }\end{array}$ & $10,6 / 11,0$ & $13,2 / 15,0$ \\
\hline $\begin{array}{l}\text { 4. Модифіковане лляне волокно, отримане } \\
\text { з емульсуванням КХП з етильованим } \\
\text { нонілфенолом АФ9-10 і подальшим } \\
\text { лужним варінням }\end{array}$ & $20,0 / 21,0$ & $67,5 / 75,0$ \\
\hline
\end{tabular}

Примітка: у чисельнику дробу наведено показники для вихідного короткого волокна № 2, у знаменнику - для короткого лляного волокна № 3.

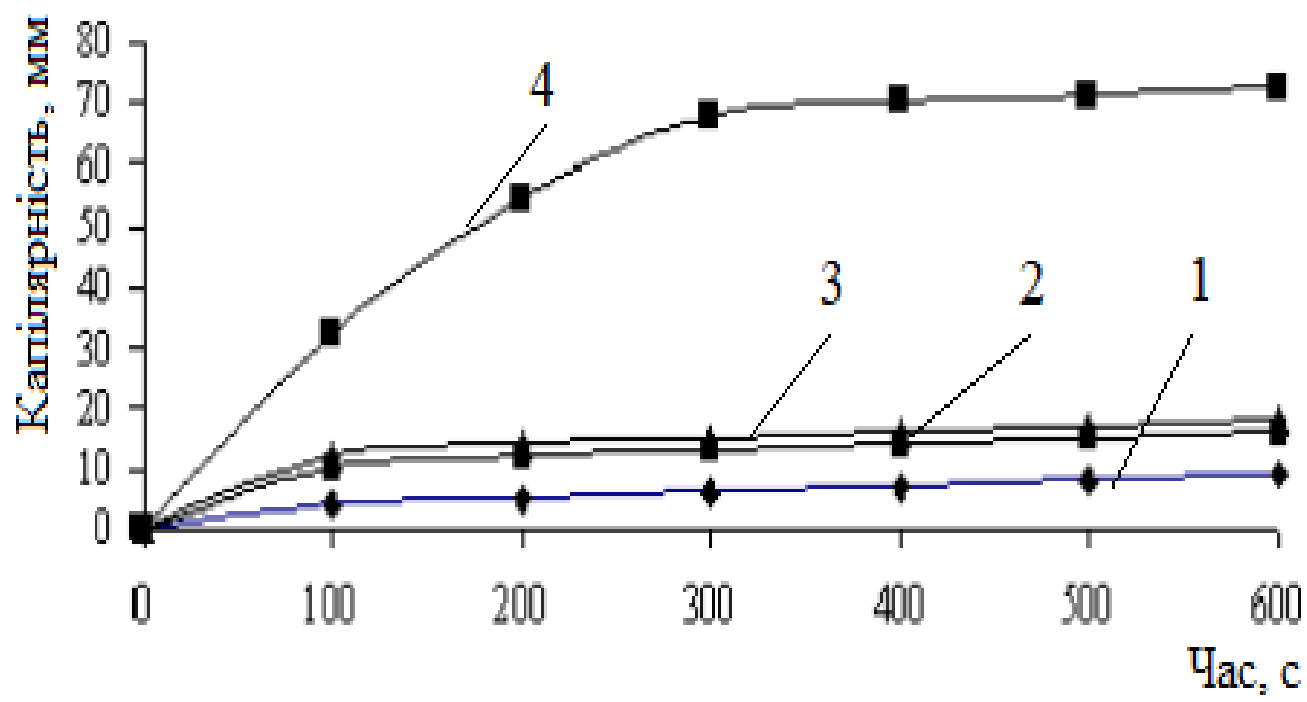

Рис. 1. Залежність капілярності від часу змочування для короткого лляного волокна № 3 :

1 - вихідне коротке волокно № $3 ; 2$ - модифіковане лляне волокно, отримане 3 емульсуванням КХП з додецилбензолсульфокислотою; 3 - модифіковане лляне волокно, отримане з емульсуванням КХП з етильованим нонілфенолом АФ 9-10; 4 - модифіковане лляне волокно, отримане з емульсуванням КХП з етильованим нонілфенолом АФ 9-10 і подальшим лужним варінням 
Розволокнене коротке лляне волокно, що не пройшло лужного варіння, також має гідрофільні властивості, проте капілярність його не перевищує 4,0 15,0 мм, а поглинальна здатність 8,5 - 11,0 г/г.

Значне підвищення капілярності волокна (до 67,5 - 75,0 мм) в процесі лужного варіння в оптимальних умовах пояснюється депектинізацією, делігніфікацією та розщепленням комплексних волокон на більш тонкі комплекси.

Розволокнення комплексів технічного волокна сприяє збільшенню його пористості, що позитивно позначається як на підвищенні капілярності, так і на поглинальній здатності досліджуваного матеріалу. Внаслідок цього збільшується площа контакту рідини з волокном. Крім того, на капілярне підняття води і кількість іiі, утримувану волокном, впливає не тільки капілярно-пориста структура зразків, але й такі чинники, як гідрофільність поверхні макро- та мікрокапілярів лляного волокна й доступність активних груп целюлози для фізичного закріплення рідини.

Під час лужного варіння відбувається не тільки гідролітичне розщеплювання пектинів, геміцелюлоз, омилення воскоподібних речовин, руйнування лігніну, але й модифікація самої целюлози. Втрати маси при лужному варінні становлять 17 - $25 \%$. Слід також зауважити, що ступінь звільнення від лігнінового компонента при обробці лляного волокна в оптимальних умовах для лужного варіння дорівнює $40-58 \%$.

На санітарно-гігієнічні властивості лляного матеріалу більшою мірою впливає руйнування зв'язків у системі целюлоза - полісахариди - лігнін. Модифікація целюлози, що має місце при високотемпературному лужному варінні, сприяє поліпшенню поглинальної здатності волокна. Так, поглинальна здатність короткого модифікованого лляного волокна № 2 після лужного варіння становить 20,0 г/г, а для короткого модифікованого лляного волокна № $3-21,0$ г/г.

Варіння лляного волокна проводили однофазним лужно-перекісним способом. При такому способі можна одержати високоякісне модифіковане льоноволокно й скоротити витрати на виробництво медичної гігроскопічної вати.

Варіння здійснювали в лабораторному автоклаві. Хімічна обробка має на меті в основному відбілювання волокна за рахунок окислення пігментних речовин, що містяться у ньому, та взаємодію компонентів варильного розчину з лігніном і білковими речовинами.

Продукти розпаду лігніну та білків, що утворюються в процесі очищення, видаляються при лужному варінні. Склад розчину для варіння 
волокна: гідроксид натрію - 7 г/л, метасилікат натрію - 5 г/л, перекис водню (30 \%)-5-6 г/л, змочувач - 0,5 г/л; тривалість лужно-перекісного варіння - 3540 хв.

Варіння при $100{ }^{0} \mathrm{C}$ забезпечує показники капілярності та поглинальної здатності лляного волокна, що відповідають вимогам ГОСТ 5556-81 для гігієнічної вати (табл. 2).

Таблиця 2

Якісні показники модифікованого лляного волокна, одержаного після варіння

\begin{tabular}{|c|c|c|c|c|}
\hline $\begin{array}{c}\text { Умови обробки та вимоги } \\
\text { ГОСТ 5556-81 }\end{array}$ & $\begin{array}{l}\text { Поглинальна } \\
\text { здатність, г/Г }\end{array}$ & $\begin{array}{l}\text { Капіляр- } \\
\text { ність, мм }\end{array}$ & $\begin{array}{l}\text { Засміче- } \\
\text { ність, \% }\end{array}$ & $\begin{array}{l}\text { Вихід, } \\
\%\end{array}$ \\
\hline $\begin{array}{l}\text { Лужно-перекисне варіння при } \\
100^{\circ} \mathrm{C} \text { : } \\
\text { волокно № } 2 \\
\text { волокно № } 3\end{array}$ & $\begin{array}{l}20,0 \\
21,0\end{array}$ & $\begin{array}{l}60 \\
70\end{array}$ & $\begin{array}{l}0,73 \\
0,70\end{array}$ & $\begin{array}{l}72,5 \\
70,0\end{array}$ \\
\hline $\begin{array}{l}\text { За ГОСТ 5556-81: } \\
\text { для очної вати } \\
\text { для хірургічної вати } \\
\text { для гігієнічної вати }\end{array}$ & $\begin{array}{l}21 \\
20 \\
19\end{array}$ & $\begin{array}{l}77 \\
70 \\
67\end{array}$ & $\begin{array}{l}0,10 \\
0,30 \\
0,70\end{array}$ & $\begin{array}{l}80 \\
80 \\
80\end{array}$ \\
\hline
\end{tabular}

Основними стадіями технологічного процесу отримання медичної гігроскопічної вати з модифікованого короткого льоноволокна є:

1. Фізико-хіміко-механічна модифікація короткого лляного волокна 3 емульсуванням комплексним хімічним препаратом [8].

2. Варіння волокна з відбілюванням, сушіння та транспортування його на чесальну дільницю.

3. Розпушування та часткове видалення костриці й смітних домішок.

4. Чесання, пакування та транспортування вати на склад, у разі потреби - стерилізація.

\section{Висновки та перспективи подальших досліджень.}

1. В результаті проведених досліджень були визначені санітарногігієнічні властивості модифікованого льняного волокна, отриманого 3 короткого льняного волокна різних номерів за трьома способами.

2. Аналіз отриманих результатів свідчить, що використання нової науково обгрунтованої технології дозволяє отримати модифіковане лляне волокно, яке може бути використано для виготовлення медичної гігієнічної вати та інших товарів медико-гігієнічного призначення. За розробленою 
технологічною схемою з модифікованого волокна виготовлено гігієнічну вату 3 показниками капілярності 70 мм (67 мм за [10]) і поглинальною здатністю 21 г/г (19-20 г/г за [10]).

Слід зазначити, що переробка волокна, яке має грибкове зараження, в вату не вдається. Навіть при інтенсифікації режимів варіння та відбілювання, часто спостерігається непробіл і низька поглинальна здатність волокна. В технічні умови на сировину повинна бути внесена вимога, що забороняє використовувати для виготовлення медико-гігієнічних товарів волокно 3 грибковим зараженням, і дана методика його розпізнавання, наприклад, аналіз поперечних зрізів методом світлової мікроскопії.

\section{Список використаних джерел}

1. Вата из короткого льноволокна. [Електронний ресурс] - Режим доступу: http://xn--80aa3acnwr.xn--p1ai/vata/.

2. Живетин В.В. Лён и его комплексное использование / Живетин В.В., Гинзбург Л.Н., Ольшанская О.М.. - М.: Информ-знание, 2002, - 400 с.

3. Льняная вата. [Електронний ресурс] - Режим доступу: https://www.sb.by/articles/lnyanaya-vata.html.

4. Живетин В.В. Льняное сырье в изделиях медицинского и санитарногигиенического назначения / В.В. Живетин, Б.П. Осипов, Н.Н. Осипова // Рос. хим. ж. (Ж. Рос. хим. об-ва им. Д.И.Менделеева).- 2002. № 2. - С.31-35.

5. Рыжов А.И. Медицинские изделий из лубяных волокон // Текстильная промышленность.- 1998.- №3.

6. Kozlowski R. Creen fibres and their Potential and Research into New Uses / R. Kozlowski, S. Manys // FAO Intercessional Consultation on Fibres, 15-16 November, 1999. - P. 123-128.

7. Cierpucha W., Kozłowski R., Mańkowski J., Waśko J., Mańkowski T. Applicability of Flax and Hemp as Raw Materials for Production of Cotton-like Fibres and Blended Yarns in Poland. // FIBRES \& TEXTILES in Eastern Europe. 2004, Vol. 12, No. 3 (47). - P. 13-18.

8. Пат. № 18253 Україна, МПК D 01 G 1/00. Спосіб отримання модифікованого лляного волокна: Пат. № 18253 Україна, МПК D 01 G 1/00. Т.О. Кузьміна, С.С. Бабіч, Л.А. Чурсіна (Україна). - № 2006 01414; Заявл. 13.02.2006; Опубл. 15.11.2006, Бюл. № 11. - 3 с.

9. Кузьміна Т.О. Модифіковане лляне волокно з широким діапазоном властивостей // Вісник Херсонського національного технічного університету. - 2010. - № 1 (37). - С. 84-91.

10. Вата медицинская гигроскопическая. Технические условия ГОСТ 5556-81.[Введен 1982-07-01]. - М.: ИПК Изд-во стандартов, 2003. - 14 с. - (Межгосударственный стандарт).

Цель. Исследование гигроскопических свойств модифицированного льняного волокна и возможности получения из него гигиенической ваты.

Методика. Во время исследования использовали стандартные методы определения физико-механических и гигроскопических свойств волокнистого материала, обработку результатов исследования проводили методами математической статистики. 
Результаты. Модификация короткого льняного волокна дает возможность сократить затраты на производство широкого ассортимента лечебной одежды $и$ материалов, поэтому актуальным является анализ влияния различных технологических приемов переработки короткого льноволокна на его санитарно-гигиенические свойства.

Модифицированное льняное волокно, полученное при выполнении данной работь с применением эмульсирования комплексными химическими препаратами (КХП) на основе фосфата карбамида и поверхностно-активных веществ перед механической обработкой, может быть использовано для получения медицинской ваты, поскольку имеет такие качественные показатели: средняя массодлина 29,8 мм (при требованиях 18,5-30 мм); линейная плотность 0,85 текс при требованиях 0,20-0,90 текс) содержание костра и сорных примесей 1,25\% (при требованиях 1,25-2,0\%).

Были определень показатели санитарно-гигиенических свойств модифицированного льняного волокна, полученного различными способами. Установлено, что ни один из этапов модификащии так не влияет на поглощяающую способность и капиллярность волокна, как варка.

Значительное повышение капиллярности волокна (до 67,5 - 75,0 мм) в процессе щелочной варки в оптимальных условиях объясняется депектинизациею, делигнификациею и расщеплением комплексных волокон на более тонкие комплексы.

Модификация иеллюлозы, которая имеет место при высокотемпературной щелочной варке, способствует улучшению поглощающей способности волокна. Так, поглотительная способность короткого модифицированного льняного волокна № 2 после щелочного варки составляет 20,0 г / г, а для короткого модифицированного льняного волокна № 3 - 21,0 г / г.

Варку льняного волокна проводили однофазным щелочно-перекисным способом. При таком способе можно получить высококачественное модифицированное льноволокно и сократить затраты на производство медицинской гигроскопической ватьл.

$B$ результате проведенных исследований разработана научно обоснованная технология получения модифищированного льняного волокна, которое может быть использовано для изготовления медицинской гигиенической ваты и других товаров медикогигиенического назначения.

Научная новизна. Обоснована возможность использования модифицированного льняного волокна для изготовления гигиенической ваты.

Практическая значимость. Разработан технологический режим получения медицинской гигиенической ваты с использованием щелочно-перекисной варки модифицированного льняного волокна.

Ключевые слова. Модифицированное льняное волокно, капиллярность, поглотительная способность, медицинская гигиеническая вата.

Purpose. Investigation of the hygroscopic properties of modified flax fibers and the possibility of obtaining hygienic wadding from it.

Methodology. During the researches we used required by national standards applicable methods for determining the physical, mechanical and hygroscopic properties of the fibrous material, to process the research results were used methods of mathematical statistics.

Findings. The modification of short flax fiber can reduce the cost of medical clothing and materials. Therefore, it is necessary to investigate the impact of processing technology on short flax fiber sanitary and hygienic properties.

Modified flax fiber obtained during this work with the use of emulsification of composite chemical agent (CCA) on the basis of urea phosphate surface-active substances before mechanical treatment, can be used to obtain medical wadding because it has such qualitative 
indicators: the average mass length 29,8 $\mathrm{mm}$ (at requirements 18,5-30 mm); linear density 0,85 tex (at the requirements of 0,20-0,90 tex); the content of shives and impurities 1,25\% (at the requirements of 1,25-2,0\%).

The indicators of sanitary and hygienic properties of modified linen fibers, obtained in different ways, were determined. It has been established that none of the modification stages does not affect the absorption capacity and capillary fiber as boiling.

Significant increase of the fiber capillarity (up to 67,5-75,0 $\mathrm{mm}$ ) in the process of alkaline boiling under optimal conditions due to depectinization, delignification and splitting of complex fibers into more subtle complexes.

Modification of cellulose, which occurs at high-temperature alkaline boiling, improves the absorption capacity of the fiber. Thus, the absorption capacity of short modified flax fiber №2 after alkaline boiling is 20,0 g/g, and for short modified flax fiber №3-21,0 g/g.

Boiling of flax fibers was carried out by a single-phase alkali-peroxide method. With this method, you can get high-quality modified flax fiber and reduce the cost of production of medical hygroscopic flax wadding.

As a result of the research, a scientifically based technology for the production of modified flax fibers, which can be used for the production of medical hygiene wadding and other medicaly hygienic goods, has been developed.

Originality. The possibility of using modified flax fibers for manufacturing hygienic wadding is substantiated.

The practical value. The technological mode of obtaining medical hygienic wadding with the use of alkali-peroxide boiling of modified flax fibers has been developed.

Keywords. Modified flax fiber, capillarity, absorbency, medical hygienic wadding.

Рекомендовано до публікачіі доктором технічних наук, професором Херсонського НТУ Валько M.I. Дата надходження до редакиії 25.01.2019 р. 